\title{
Fetishism and the Language Commodity: A Materialist Critique
}

\begin{abstract}
Over the past 10 years, an emerging body of research in linguistic anthropology and applied linguistics has made the argument that recent global political-economic developments have led to the commodification of language. In focusing on how language is seen as a tradeable commodity, the process of commodification is portrayed as a principally discursive event, where value and commodity status are attributed to languages. However, the notion of both value and of commodities themselves as discursive matters stands in contrast to Marxist and classical political economy where commodities have value only insofar as they are congealed embodiments of human labour, expended in production processes where labour stands in relation to capital. In juxtaposing the 'language commodity' with the commodity of Marxist political economy, and in drawing on Marx's notion of commodity fetishism, we argue that though language may appear to be a commodity, it is not one, as language itself is not a product of labour. We conclude by discussing what a closer engagement with the more material concerns of production offer political economy approaches to language in addressing an 'ideal' and 'material' epistemological divide (Gal 1989; Irvine 1989; Friedrich 1989; Shankar \& Cavanaugh 2012).
\end{abstract}

\section{Introduction}

Over the past 10 years, an emerging body of research has made the argument that recent global political-economic developments have led to the commodification of language. This is evidenced in a series of edited monographs and journal special issues that are centred on the notion of language as commodity (e.g. Duchêne \& Heller eds. 2012; Park \& Wee 2012; Tan \& Rubdy eds. 2008; Heller, Jaworski \& Thurlow eds. 2014; Muth \& Del Percio eds. Forthcoming; Muth \& Ryazanova-Clarke eds. 2017; Flubacher \& Del Percio eds. 2017). The emergence of language as a commodity is viewed as due to a recent historical shift which has caused phenomena of every type - whether material or social - to be seen increasingly in terms of economic exchange. However, while there is an evident preoccupation with the monetisation of everyday life on the part of neoliberal economists and politicians, that 'things' are seen in terms of economic exchange, and that 'things' are economically exchanged, are two quite different issues. Our reference points are classical political economy (Smith 2003 [1776]) and the commodity theory of Marx (1990 [1867]), which is based on this. A central thread which runs through the political economy of Marx is the notion of fetishism - that there is a level of appearance in our daily experience of exchange which it is necessary to penetrate in order to better understand the workings of capitalism. Drawing on this notion of fetishism, we argue that rather than language itself becoming commodified, it is more the case that language appears as a commodity, but is not a commodity, as the element that gives real commodities their economic value - expended labour, does not apply to language, because, as some scholars have pointed out, languages themselves are not products of labour (Holborow 2015; Gray 2016; Block $2014,2018)$. In this article, therefore, when we refer to 'the language commodity', we do so as a means to engage with a scholarly literature which falls into two more or less generalisable groupings. On the one hand, there is a literature which claims that language itself is a commodity or has become one (Alsagoff 2008; Heller 2010b; Park \& Wee 2012; Rassool 2007; Singh \& Han 2008; Tan \& Rubdy 2008; Tupas 2008), and on the other, there is a literature which widely utilises the phrase language as commodity for engaging in this discussion (Da Silva, McLaughlin \& Richards 
2007; Heller 2003; Muth \& Razanova-Clarke 2017; Singh \& Han 2008). Within either grouping no attempt has been made to distinguish between the conceptions of language being or having become a commodity, and language as commodity. Indeed, Heller (2003, 2010b) and Singh \& Han (2008) appear to use these descriptions interchangeably. We thus view the phrasings language as commodity and language being or having become a commodity as synonymous designations for what we refer to in this article as 'the language commodity'. Taking this a step further, it is also not the case that the literature deals with the commodification of language as an 'open process' whereby language is seen as only operating more and more like a commodity, but without actually being or becoming a commodity. Rather, in the descriptions which are employed there would appear to be an explicit endpoint to this process suggested, and that language is not to be understood as only 'commodified' to a greater or lesser extent, but also becomes a commodity in its own right.

In this article, we wish it to be understood that we do not subscribe to the notion of language as a commodity, but rather only to that of language appearing to be a commodity. It is our contention that work that views language as a commodity has, with the few exceptions already noted, almost exclusively dealt with language appearing as a commodity, and has done so by treating the process of commodification as a principally discursive event. As a consequence, and in the vein noted in a recent position paper by Kubota (2016), a good deal of the scholarship on language commodification finds itself in the awkward position of tacitly aligning itself with a neoliberal conception of value, in which value is construed solely in terms of 'desire' or 'want' (i.e. that value is merely 'in the eye of the beholder' so to speak, and bears no relation to the expended labour embodied in commodities), as we discuss below. This in turn has led to an implied acceptance of neoliberal economic and ideological orthodoxy in respect of the current preoccupation with human capital (Becker 1993), and as part of this, the reduction of languages and their speakers to 'bundles of skills' (Urciuoli, 2008; XAuthor, 2018, this issue). The distinction between being a commodity and appearing to be a commodity comes into focus when the language commodity and the commodity of classical and Marxist political economy are juxtaposed with one another. In this article we offer such a juxtaposition, and make the argument that language is not a commodity, but has largely been discussed as such due to a misrecognition of the commodity, and of commodities in general. We seek to penetrate the surface level of appearances, and to reintroduce the material into the discussion of language and the commodity. By this we mean that we wish to go beyond the discursive commodification of language in a linguistic market - although as we show this distinction is not always consistently made - and highlight the importance of the production and exchange of commodities in general, for and within the economic market. In so doing we wish to argue that applied linguists and linguistic anthropologists might more effectively engage in the critique of capitalism as a mode of production which is dedicated to, and defined by, the endless production of commodities, and so also with the critique of real-world problems in which language is a central issue (Brumfit 1991).

In the pages which follow, we wish to deal with the treatment of the language commodity by charting a course from what we consider to be primarily a discursive or 'ideal' understanding of the commodity to one which, following Marx, is much more materialist in its conception, and which places labour at its heart. We feel that this makes possible a more nuanced as well as rigorous analytical understanding of the relationship of language to labour and to the production of actual commodities more generally. In the effort to construct a 'bridge-like' passage from the ideal to the material, we first locate the discussion of the language commodity in relation to political economy 
approaches to language. We then present an in-depth discussion of the commodity as it is understood by Marx, and of the concept of commodity fetishism in particular. It is through this concept that the distinction between the appearance and the reality of the commodity is most vividly captured, and also for us the impossibility of the language commodity itself. Our analysis shows that in the construction of the language commodity scholars have abstracted the component of production away from the commodity so that embodied labour as an index of value is removed, and what remains is a notion of value as constituted by desire, and which has been discursively conferred. It is this abstraction from the production of the commodity which has enabled scholars to view language itself as having become a commodity readily mobilised and exchanged in the market place. This leads us to a discussion of the historical specificity or, more accurately, 'non-specificity' of the language commodity form, from which we conclude that the instrumental view of language (Wee 2008) is not a new phenomenon, and is certainly not confined to late capitalism, but has a long history which pre-dates capitalism itself. From here we return to the concept of value to show how its discursive framing in terms of desire has had the undesirable effect of aligning applied linguistic conceptions of value with neoliberal conceptions of the same. The article then draws to a close with a call for a reintegration of the material in political economy approaches to language and the commodity which a Marxist analysis makes possible. In this way, by reintroducing the material, it is our aim to offer 'a bridge' of sorts from the ideal to the real in applied linguistic and anthropological discussions of this subject.

\section{Political Economy, Linguistic Anthropology and Applied Linguistics}

The uptake of language commodification in anthropology and applied linguistics reflects a recent interest in a turn to political economy (Block 2018) in order to explore the interrelations of the political, the economic and the social with regard to language. This emergent body of research attempts to answer calls for more interdisciplinary approaches to doing applied linguistics (Rampton 1997), while also being a reaction to the way the 2007-8 global financial crisis has highlighted the gap between the promises of neoliberal capitalism and the political-economic realities which undermine those promises, including the linguistic ones (Holborow 2015). The recent turn to political economy began to emerge in the landmark linguistic anthropological work of Susan Gal (1989), Judith Irvine (1989), and the less often credited Paul Friedrich (1989), who separately called for a rapprochement between 'idealists' and 'materialists' on each side of an epistemological divide, where "'idealists' specializing in cultural and linguistic phenomena [and] 'materialists' investigating economy and ecology" (Gal 1989: 346-347) work within a "false dichotomy" (Irvine 1989: 263). They each argued that what was needed was the integration of the two. In recognition of the redundancy of the ideal/material distinction, Gal pointed to an emergent "set of themes in current anthropological and linguistic research that can be read as investigations of the links among language structure, language use, and political economy" (1989: 346).

However, the extent to which scholars have engaged deeply with the political and economic workings of neoliberal capitalism has come into question. Ricento, for example, bemoans a general "lack of sophistication in political economy" (2012: 32), and Grin (2003) the metaphorical application of economic terms and concepts to work that deals with language. More generally, Bruthiaux (2008) criticizes the "reluctance of many applied linguists to consider the economic dimension of globalization" (2008: 20), leading to a one sided 'cultural' discussion of globalization at the expense of the economic. Similarly, Block, Gray \& Holborow describe political economy as a "blind spot" in the recent sociolinguistic interdisciplinary turn (2012:1), where scholars "ignore the economic and 
material bases of human activity and social life, or only deal with it in the most cursory of manners" (2012: 3-4). Indeed, the extent to which a political economy approach to language has bridged the ideal/material divide remains questionable. While work such as Shankar \& Cavanaugh's 'language materiality' (2012), where language is 'objectified' rather than 'commodified' ( $p .362$ ), goes some way towards this, we wish to argue that work which frames language as a commodity has thus far engaged with the more material concerns of political economy in ways which are quite limited. As Block (2018) points out, the more 'material' work on the economics of language (Grin 2014; Grin et al. 2010), where the paradigms, concepts and tools of mainstream economics are taken up, seems to have had a limited impact upon the work of linguistic anthropology and applied linguistics.

Given the frequency with which the literature uses the terminology fundamental to a political-economic discussion of the commodity, particularly use-value and exchange-value, little reference is given to key figures of political economy such as Smith, Ricardo, and Marx (Block 2014, 2018). Though Marx writes extensively on the commodity - the three volumes of Capital are in effect premised on it - references to his work in the literature on language commodification are rare. For example, in the widely-cited volume Language in Late Capitalism: Pride and Profit, edited by Duchêne \& Heller (2012), within which commodification is a major theme, no direct reference to Marx is to be found. Neither is Marx referenced in Flubacher \& Del Percio's more recent edited volume on Language, Education and Neoliberalism (2017). Similarly, the initial ground-breaking work of Rossi-Landi $(1975,1983)$ on language and economy from a Marxist perspective is also seldom mentioned or discussed. Elsewhere, in works where reference to Marx is present, his work is afforded only brief mentions. For example, within the volume Language as Commodity (Tan \& Rubdy eds. 2008), the sole reference to Marx comes from Tan (2008), who credits Marx with the development of the notion of commodification within capitalism. It is noticeable, however, that this is not drawn from Capital or Grundrisse, which is where Marx's theory of the commodity is principally to be found, but from the pages of the Communist Manifesto (Marx \& Engels 1967/1848), whose main purpose was not to serve as a theoretical treatise on capitalist political economy, but to act as a political call to arms.

\section{Commodity as Metaphor? The Double life of the Language Commodity}

According to Park \& Wee (2012), "English has become deeply commodified. This much is undeniable" (p.186). Park \& Wee are not alone in taking this view. Heller (2003), Duchêne \& Heller (2012), and Rubdy \& Tan (2008), likewise make the claim that language in and of itself has become commodified. In addition to those just mentioned, the following literature discusses either languages themselves or linguistic products as commodities: Alsagoff (2008); Boutet (2012); Bruthiaux (2008); Cameron (2005); Da Silva, McLaughlin \& Richards (2007); Del Percio \& Duchêne (2012); Duchêne (2009); Gray (2010); Gal (2016); Irvine (1989); Heller (2002, 2010, 2010b); Heller \& Duchêne (2016); Heller, Jaworski \& Thurlow (Eds. 2014); Heller, Pujolar \& Duchêne, (2014); Hoon (2008); Rahman (2009); Rassool (2007); Singh \& Han (2008); Tupas (2008); Wee (2008). The scope of objects of commodification runs the gamut from the macro to the micro, from languages themselves as commodities (Alsagof 2008; Heller 2010b; Park \& Wee 2012; Rassool 2007; Tan \& Rubdy 2008; Singh \& Han 2008), to individual utterances (Irvine 1989), and from concrete objects like ELT course books (Gray 2010) to abstract notions such as pride (Del Percio \& Duchêne 2012). Though the object of commodification varies, there is consensus on two key points. Firstly, that objects or things which once were not considered commodities, or were 'non-commodities', have somehow become commodities - i.e. they have become commodified in some sense - and second, that this 
commodification is related to more recent global political and economic developments, often referred to as the 'new economy' (Del Percio \& Duchêne 2012; Heller 2003; Heller 2010; Heller \& Duchêne 2012; Heller \& Duchêne 2016; Heller, Pujolar \& Duchêne 2014; Park \& Wee 2012). Thus, it is argued by Heller (2010) that "Through the various ways in which language has acquired centrality in the work process and work products of the new economy, language has become a commodity itself and, therefore, acts as a resource to be produced, controlled, distributed, valued, and constrained" (p. 108). Heller then summarizes the greater body of work in maintaining that the commodification of language is the result of the particular political-economic conditions of recent decades, and is thus historically specific to the present era of capitalism (passim).

Scholars such as Block $(2014,2018)$ and Holborow $(2015)$ have pointed to a lack of theoretical underpinning of the commodity in work on language commodification, with terms such as commodity and commodification often lacking explicit definition and being used largely in a metaphorical sense with tacitly assumed understandings. Holborow (2015) also argues that it is not just the notion of the commodity, but the concepts of the market too that have "become so commonplace [...] it is often unclear whether they are intended to be taken literally" (p.52). The answer to whether language is discussed as a commodity in a metaphorical or economic sense - like a commodity or really as a commodity (i.e. as something tradable on the economic market) - is often unresolved. For example, Park \& Wee note how "language varieties, linguistic utterances, accents, and their embodiments are all like commodities on a market - the linguistic market. The market metaphor points to how one might use such linguistic resources as a basis for gaining some other form of material or symbolic goods" (Park \& Wee 2012: 27; emphasis added). Here, the use of commodity and market, in relation to Bourdieu's (1991) notion of markets within which one can trade various forms of symbolic capital, are explicitly stated as metaphors. In parallel with Bourdieu, Rossi-Landi (1977) also makes use of his own distinctive notions of linguistic capital and the linguistic market. However, the key difference between this work, and the more recent work that draws on Bourdieu, lies in how Rossi-Landi sees linguistic capital as circulating exclusively within linguistic markets, whereas the language commodity of more recent linguistic anthropological work appears to lead a double-life, existing as both a metaphorical and as an economic commodity which circulates not only in linguistic markets but also in the conventional markets of material goods. Here are Park \& Wee again: "English is seen as an economic resource, a commodity that can be exchanged in the market for material profit" (2012: 124; emphasis added). However, if language, in this case English, may be exchanged in the conventional market (for money or other commodities), then it is not sufficient that it simply be seen as an economic resource. Rather, it is an economic resource as a consequence of its function in exchange. This jump from the discursive (i.e. metaphorical) commodification of language to the concrete conventional exchange of the market has been criticised by McGill (2013), who notes that work on the commodification of language merely highlights the "framing" of language as a commodity which "is not at all the same thing as showing the actual consumption of language as a commodity" (p. 85). Such criticism has been shrugged off by Kelly-Holmes as overly literalist, suggesting that it is indeed primarily as a metaphor that language as a commodity is meant.

$\mathrm{He}$ [McGill] takes the literalist position that there has to be an actual exchange of money for 'language', and sociolinguistic studies have to show how the use of a particular language, variety, and so on actually attracts money [...] McGill's literalist stand, however, is in contrast to Bourdieu's metaphorical use of 'the market' for language, which has been so influential in contemporary 
sociolinguistics, and we can see a particular line of influence from Bourdieu to the current work on political economy and commodification studies. (Kelly-Holmes 2016: 169)

However, Kelly Holmes' insistence that recent work treats the language commodity metaphorically within the bounds of metaphorical Bourdieusian markets seems somewhat at odds with much work in linguistic anthropology which places language in the conventional market of economics. On this matter, most scholars appear unequivocal. Gal (1989) for example discusses how "Language may also constitute a resource in a more narrowly economic sense as well, when linguistic practices or speech acts (e.g. condolences on a greeting cards) are produced and sold as commodities" (p. 353; original parenthesis). Similarly, for Irvine (1989), "linguistic elements and utterances may themselves be goods and services, exchangeable against other goods and services, including material goods and cash" (p. 256). Heller, Pujolar \& Duchêne (2014) make explicit the interaction between the language commodity and the non-metaphorical 'conventional' market where "Commodification' is the expression we use to describe how a specific object or process is rendered available for conventional exchange in the market" (p. 545 emphasis added). Heller \& Duchêne (2016) go so far as to state that the way that "linguistic material of a variety of forms was increasingly presented as an element of economic exchange [...] was no metaphor" (p. 140), and that "The idea of language as commodity helps us understand part of what people are trying to do with language [...] not just in how they think of it but in how they concretely try to turn it into an exchangeable resource with measurable value in economic terms" (p. 144). In response to Grin's (2014) critique that work on the language commodity metaphorically appropriates terms from economics and "offers no economic angle" (p.19), Heller \& Duchêne insist that the language commodity and the market are not just meant as metaphors, in stark contrast with Kelly-Holmes' defence discussed above. In addition to our call for a closer engagement with the more material concerns of political economy in discussions of the language commodity, the insistence on the interrelation between language seen as a commodity metaphorically and the historically specific material world of late capitalism that Heller \& Duchêne present is also a position which this article questions, as will be discussed at a later point. To date, the dialogue between those who critique the notion of language as commodity (Grin 2014, McGill 2013) and those who defend it (Heller \& Duchêne 2016; Kelly-Holmes 2016), has focused on what Heller \& Duchêne (2016) describe as the "discomfort with the ontological status we accord to language and its commodification" (p. 145), i.e. with the reduction of language and languages to a commodifiable thing. In this article, we suggest that there is indeed an ontological problem with the language commodity, though our focus is on the ontological status of the commodity rather than of language itself. It is to the commodity which we now turn.

\section{The Commodity in Marxist Political Economy}

The commodity, as discussed in both Marxist political economy and the classical political economy to which it is a response, is a product of human labour, produced for exchange in the market. It appears as a duality of two distinct values, use-value and exchange-value. In general terms, usevalue is the utility of a thing, the way in which "its qualities satisfies [sic] human needs of whatever kind" (Marx 1990 [1867]: 125). The exchange-value of a thing is "the quantitative relation, the proportion, in which use-values of one kind exchange for use-values of another kind" (Marx 1990 [1867]: 126), whether that exchange is for money or for another commodity. In Marx's words, 
[Commodities] are only commodities because they have a dual nature, because they are at the same time objects of utility [use-value] and bearers of value [exchange-value]. Therefore, they only appear as commodities, or have the form of commodities, in so far as they possess a double form. (Marx 1990 [1867]: 138, emphasis and parentheses added).

It is crucial to Marx's conception that commodities only appear as this duality. In other words, there is more than use-value and exchange-value at stake. In order to illustrate how it is that commodities of endless varieties are commensurable and exchangeable in the market, Marx identifies a common property which all commodities share. Marx works through this point as follows,

[F]irstly, valid exchange-values of a particular commodity [e.g. $X$ amount of silk $=Y$ amount of gold] express something equal, and secondly, exchange-value cannot be anything other than the mode of expression, the 'form of appearance' of a content distinguishable from it. [...] It signifies that a common element of identical magnitude exists in two different things, in 1 quarter of corn and similarly in $x$ cwt of iron. Both are therefore equal to this third thing, which in itself is neither the one nor the other. Each of them, so far as it is exchange value, must therefore be reducible to this third thing. (Marx 1990 [1867]: 127; parentheses added)

In echoing Smith and Ricardo, Marx concludes that the property which is common to all commodities is that of embodying a certain quantity of labour: '[H]uman labour-power has been expended to produce them, human labour is accumulated in them. As crystals of this social substance, which is common to them all, they are values - commodity values' (Marx 1990 [1867]: 128). This explains why some commodities have more value than others in the market, even when supply and demand are in equilibrium - a diamond requires a good deal more labour to produce than a potato for example. In a free market of 'valid' exchange, it is the relative quantities of labour expended in production that regulate the value of commodities. This accords with the classical political economy of Smith.

At all times and places, that is dear which it is difficult to come at, or which it costs much labour to acquire; and that cheap which is to be had easily, or with very little labour. Labour alone, therefore, is [...] the ultimate and real standard by which the value of all commodities can at all times and places be estimated and compared. (Smith 2003 [1776]: 47)

Recognition of the distinction between exchange-value and embodied or 'real' value (that is, between the price of a thing and the labour expended to produce it), is critical for Marx. Rather than the exchange-value or price of a commodity being determined because of some intrinsic quality it possesses, or by means of the forces of supply and demand - though these factors are not without their significance - it is the quantity of labour needed to produce the commodity that is ultimately key to the regulation of its price in the free market where equilibrium between supply and demand exists.

The Abstraction of Value Production from the Concept of the Language Commodity If from Marx's perspective expended labour is the property which makes all commodities exchangeable, it behoves us to consider how the commodity is presented in political economy approaches to language. For Park \& Wee, for example, "A commodity is a thing that is produced with the purpose of being sold in 
the market, of being offered for exchange" (2012: 125, emphasis added). This definition, which appears to accord with the Marxist and classical political economy position just outlined, is followed by the view that "When we speak of the commodification of language, we are speaking of the conditions under which language comes to be valued and sought for the economic profit it can bring through exchange in the market" (p.125, emphasis added). Here, the notion of the language commodity as a thing that is 'produced' appears to have been abstracted away. Rather than the commodity as something that is produced by labour, which as Holborow (2015) and Block (2014, 2018) have pointed out, is always problematic for a concept like language, the commodity instead 'comes to be valued', or has value mysteriously conferred upon it. This abstraction away from the production of value through labour, is not an isolated phenomenon, but is common to much of the literature dedicated to the commodification of language, including the body of thinking which has coalesced around the work of scholars such as Heller and Duchêne (see above for references). Though it is evident that scholars who frame language as a commodity do indeed concern themselves with the conditions of labour in various production processes (Boutet 2012; Heller 2003, 2010b; Heller, Pujolar \& Duchêne 2014), they nevertheless do not appear to view labour as a source of value production in relation to the language commodity itself.

\section{The Fetishism of the Language Commodity}

It is not so much the inconvenience, or challenge, of making the argument that language itself is a product (i.e. that it is produced by labour in some way), which we believe has led to the misrecognition of language as a commodity. It is more the case that the limited discussion of production and labour in the discussion of language as commodity, rather than simply being peculiar to work on the language commodity, is in fact a consequence of how capitalism itself functions, and of our daily lived experience of commodities and exchange. In simple terms, scholars have overlooked the realm of production in the language commodity because in the wider human experience of commodities this dimension is obscured, and this in turn has been responsible for a certain preoccupation in linguistic anthropology and related fields with how commodities - or what are taken to be commodities - appear.

Though we may well be aware that the commodities we buy are products of human labour, it is only in exceptionally rare circumstances that we would have any meaningful knowledge about the labour processes - the 'concrete labour' (Marx 1990 [1867]: 137) - which are specific to the production of those commodities. It is too impractical an undertaking for every distinct concrete form of labour to be equated with every other in exchange. Thus, Marx concludes that the myriad forms of concrete labour are necessarily reduced to labour as a social abstraction of an average expenditure of labour which he refers to as socially necessary labour-time.

Socially necessary labour-time is the labour-time required to produce any use-value [commodity] under the conditions of production normal for a given society and with the average degree of skill and intensity of labour prevalent in that society. (Marx 1990 [1867]: 129; parenthesis and emphasis added)

In this sense, value as socially necessary labour-time, is a "phantom-like objectivity" (Marx 1990 [1867]: 128), inasmuch as it is an outcome of the regulatory force of the market - universal to all commodities, yet ultimately immaterial as it is an abstraction from concrete labour, i.e. from the actual labour expended on individual commodities. In the practical day-to-day experience of 
commodities, we are inescapably limited to the commodity's appearance as a simple duality - what it is for (its use-value), and what one receives in return when one exchanges a particular commodity in the market (its exchange-value, which often takes the form of a monetary price). The practicalities of market exchange obscure the commodity's nature as a product of labour, and the material relation between money and commodity obscures how producers and consumers are socially related to one another. It is not that people are wilfully ignorant or indifferent to the notion of labour as value within the commodity, or the labour that produces it, but that one cannot 'grasp' the value of a commodity in one's experience of the purchase and sale of commodities in the marketplace: "We may twist and turn a single commodity as we wish; it remains impossible to grasp it as a thing possessing value" (Marx 1990 [1867]: 138). Marx concludes that "the social relations between [...] private labours appear as what they are, i.e. they do not appear as direct social relations between persons in their work, but rather as material [...] relations between persons and social relations between things" (Marx 1990 [1867]:166, emphasis added). Though our everyday experience is limited to the appearance of commodities, this world of appearances is not in any sense illusory. Rather, this really is how we necessarily experience the world under capitalism, and this really is how we relate to each other socially - through material commodities and money (Harvey 2010). We argue that scholars have not so much avoided the proposition of language as a product of labour, but rather, in falling in with the fetishistic view of commodities as a duality of usevalue and exchange-value, they have been led to exclude from their discussion any consideration of the concrete labour that produces value in commodities and its necessary conversion to abstract labour in exchange. By embracing the concept of language as commodity, while absenting a discussion of how that commodity may be produced or is able to realise value in exchange, the appellation 'commodity' is applied to a thing that is not produced. From a Marxist political economy perspective, it is in the fetish moment of appearance that anthropological discussions of the language commodity may be said to be primarily located. This in turn has been responsible for the confusion which exists over the classification of commodities in linguistic anthropology and related fields.

\section{Language Appearing as a Commodity}

The question to be considered is whether language really is a commodity, or whether it simply appears as a commodity. A variety of responses to this question may be found, ranging from the explicit "English in itself is sold as a product or service" (Singh \& Han 2008: 221), to discursive framings of language being 'seen as' or 'like' a commodity. With regard to the claim that English itself is a product which may be sold, this immediately again raises the complex issue of whether language can be understood as a product of labour. While Singh \& Han's discussion of linguistic markets addresses how English comes to be exchanged, production and labour are absent, and we are thus left with English as a product divorced from production and producers. It is our contention that the commodity should not be reduced to a matter of semantics, by which people mean different things by the term. Our insistence on the importance of production and labour is thus not a question of emphasis. It is not the case that we wish to discuss the commodity purely from the point of view of production while others do so from another perspective. Rather, we see the commodity as an indivisible unity of production and consumption. In other words, we hold that that which is produced, but not for exchange and consequent consumption, is not a commodity, and conversely, that which is consumed but not produced is not a commodity either. The first half of this unity, that a thing must be produced with future exchange and consumption in mind, is fairly straightforward, 
insofar as commodities are not merely produced as "use-values [things, products], but use-values for others, social use-values" (Marx 1990 [1867]: 131). The other side of the equation, that something may be exchanged which is not a product of labour, requires a return to the notion of appearances.

[Commodities] are only commodities because they have a dual nature, because they are at the same time objects of utility [use-value] and bearers of value [exchange-value]. Therefore, they only appear as commodities, or have the form of commodities, in so far as they possess a double form (Marx 1990 [1867]: 138, emphasis added).

It is our contention that appearing is not the same as being, that seeming is not the same as is. This is something we wish to stress. Though commodities appear as a duality of use-value and exchangevalue, there is always a third factor in play, and this is value (i.e. the length of socially necessary labour time required to produce a commodity on average within a world market society). However, this should not be taken as an insistence that everything which can be or is sold must therefore be a product of labour and so have value, as Marx is fully aware.

Things which in and for themselves are not commodities, things such as conscience, honour etc., can be offered for sale by their holders, and thus acquire the form of commodities through their price. Hence a thing can, formally speaking, have a price without having a value. The expression of price is in this case imaginary. (Marx 1990 [1867]: 197 emphases added)

While in Marxist political economy, commodities realise a price in exchange which is merely the 'form of appearance' of their value (the labour expended to produce them), the examples discussed above, honour, conscience etc. contain no value as no labour has been expended in their production. They are not therefore 'produced'. Thus, whatever price one puts on them has no objective grounding in the amount of labour required to produce them (value), and is, as Marx puts it, "imaginary". It is our contention that language and languages also fall into this category. They too have acquired 'the form of commodities' in the absence of any labour being expended upon them.

This distinction between a thing being a commodity and appearing as a commodity, is echoed in the work of Polanyi (2001 [1944]) for whom land, labour and money "are obviously not commodities" and their "commodity description is entirely fictitious" (p.73). Polanyi argues that if labour, and therefore people, really were to become 'fully' commodified the consequences would be disastrous.

For the alleged commodity 'labour power' cannot be shoved about, used indiscriminately, or even left unused, without also affecting the human individual who happens to be the bearer of this peculiar commodity. In disposing of a man's labour power the [market] system would, incidentally, dispose of the physical, psychological, and moral entity 'man' attached to that tag (p.73)

Though undoubtedly various forms of capitalism, not least its current neoliberal incarnation, has in numerous times and places cruelly treated people as dehumanized disposable 'inputs', it would be difficult to suggest that we have witnessed the total disposal of the 'physical, psychological and moral entity 'man', or better, 'humankind'. This is not just a moral argument, but a practical one, as such totalising commodification would destroy the very bases upon which the market is founded, 
not least of all the reproduction of human life as a means to supply the labour it needs. As Fraser argues,

[A]ttempts fully to commodify labour, land and money are conceptually incoherent and inherently self-undermining, akin to a tiger that bites its own tail. For structural reasons, therefore, society cannot be commodities all the way down. (Fraser 2014: 548).

The danger of subscribing to the commodification of everything, including language, "all the way down", is a foreclosure on the forms of resistance to the forces of the market which exist, and which are exercised by those who work in various production processes (see XAuthor, 2018, this issue). We wish to point out at this juncture, that by 'labour' we are talking specifically about the expenditure of mental and physical effort within a social relation particular to capitalism, i.e. that between capital and labour, whereby the value created by labour is appropriated by capital. There are indeed many forms of 'labour' and 'production' (in the wider sense of the terms) which do not occur within this particular relation. Though raising a child for example, involves considerable amounts of labour, it is only by taking an extremely reductive view that one could describe such unpaid "reproductive labour" or "care" (Fraser 2014: 550) as a form of 'production' which is synonymous with that of commodity production. Though the acquisition of language certainly can involve considerable physical and mental effort, to equate this kind of labour with that of capitalist production processes would come close to naturalising the capital-labour social relation. Taken to its logical conclusion, it would also recast all expenditure of human effort as commodity production. This is so regardless of whether or not an instrumental view of language learning is accepted, i.e. one where language has value in and of itself, as it is the social-relation of capital and labour which defines commodity production within capitalism. Of interest is that Rossi-Landi appears to take this route as well. He equates the labour and production involved in language with that of commodities in asserting a certain "sameness" between the production and circulation of verbal messages and commodities, as "two principle branches of one tree" (1977: 5), and where utterances and commodities share a "homology of production" (ibid: 70). However, in contrast to the more recent anthropological literature on the language commodity, Rossi-Landi's work does not attempt to tie the production of language to an historically specific context such as late capitalism or a new economy, but rather uses "production" in its general sense" (ibid: 70). In addition, he frames linguistic production in terms of the "production of a community considered in its initial and founding phase" (ibid: 78). For Rossi-Landi then, and in contradistinction to recent anthropological perspectives, the production (in its "general sense") of language is not historically specific or in any way recent, but is a feature of all historical epochs.

Commodification as Discourse and the Historical Non-Specificity of Linguistic Instrumentalism The commodification of language in linguistic anthropology and applied linguistics has, by and large, been treated as a subjective discursive process, by which a thing - language - only attains its commodity status insofar as it is seen as such. Tan (2008) for example refers to "the discourse of economic commodification" (p. 119) whereby to talk about language in terms of its economic value would appear to be tantamount to its commodification. Likewise, the focus of Wee's (2008) study concerns the shift in discourse towards what he calls 'linguistic instrumentalism'. Here language is viewed in 'economic' terms. In following Wee, Tupas (2008: 91) states that linguistic instrumentalism and commodification are synonymous. Similarly, the overarching framework of 
Language in Late Capitalism: Pride and Profit (Duchêne \& Heller eds. 2012) is also that of a discursive shift from seeing languages in terms of 'pride', in terms of identity and authenticity, towards those of 'profit' and pecuniary benefits. As Duchêne and Heller put it, "We are witnessing the widespread emergence of discursive elements that treat language and culture primarily in economic terms" (Duchêne \& Heller 2012: 3). The general consensus which emerges is that the commodification of language is indeed a discursive matter, with a significant number of contributors focusing on how government policy and its associated political discourse have come to view language increasingly in economic terms, thereby commodifying it (Wee 2008; Alsagoff 2008; Hoon 2008; Tupas 2008; Tan 2008; Kamwangamalu 2008). Hence, the common theme that runs throughout these accounts is the notion of commodification as a recent discursive shift, that is inextricably linked to late-capitalism, neoliberalism, and/or the 'new economy' (passim). However, the assertion that language commodification is a process which is historically specific to late capitalism is problematic because the discourses which treat language in economic or instrumental terms (Wee 2008) predate the changes in political economic conditions which have been identified. Latin, for example, was learned in medieval Europe with at least some degree of 'linguistic instrumentalism' and a concern for the economic and social value that knowledge of it conferred. If linguistic instrumentalism and language commodification are synonymous, as Tupas (2008) for example suggests, it becomes difficult to defend the proposition that language commodification is historically specific to contemporary capitalism. The answer to whether one accepts an example such as Latin in medieval Europe as an example of linguistic commodification, rests on a precise definition of a commodifying discourse of language, and a clearer distinction to be made between such a discourse on the one hand, and linguistic instrumentalism on the other.

The turn to the historical specificity of capitalism that the more recent literature on the commodification of language insists upon seems misplaced, and even overdone. In the case of Irvine's study of linguistic economic exchange in rural West Africa for example 'linguistic products' are not actually produced under the social relations of capitalism - there is no capitalist, no surplus value, no wages. In fact, we find in this context not the social division of labour determined by the 'invisible hand' of the free market (Smith, 2003 [1776]), but production at least partly based on a caste-system division of labour (Irvine 1989). Language is nevertheless viewed in economic terms and exchanged, and arguably, at least on the basis set more recently, would be tantamount to its commodification, even in the absence of any capitalist social relations. Given the apparent ease with which Irvine's example, from a non-capitalist context, can sit quite well alongside work explicitly concerned with language commodification within contemporary capitalism, how central the particular material realities and inner workings of late-capitalism are to work on language commodification, appears questionable. The use of Bourdieu's notions of capital and markets at the heart of many of these accounts places further doubt upon the specificity of the language commodity to 'late' capitalism. While it is beyond the scope of this article to present a comprehensive discussion of Bourdieu's extensive writing on forms of capital and markets, there is one key point we would make in regard to the claim of the historical specificity of the language commodity. This is that the various forms of capital and markets of Bourdieu's work are not contingent upon the existence of a capitalist or market society. Rather than historical and contingent, they appear as social universals irrespective of the presence of a capitalist social order. This is made explicit in Bourdieu's work, which gives centrality to "the brutal fact of universal reducibility to economics" (Bourdieu 1986: 251) in all social exchanges, be they commodities, gifts, or smiles, and where the extension of the "economic calculation to all the goods, material and 
symbolic" (Bourdieu 1977: 178) applies universally. In work on the language commodity, there is thus often a marked asymmetry between the Bourdieusian market as a universal, and the economic market which is particular to 'late' capitalism, and to which the language commodity is claimed to owe its genesis.

\section{Tacit Neoliberal Assumptions of Value}

The view of commodification as a discourse which concerns the framing of language in 'economic terms' involves talking of language in terms of value. For example, within much of the discussion on this topic there are references to how language is viewed in terms of instrumental value (Lam \& Wang 2008; Tupas 2008; Wee 2008), cultural value (Alsagoff 2008; Lam \& Wang 2008), value of identity (Hoon 2008), market value (Coulmas 1992; Kamwangamalu 2008; Lam \& Wang 2008), symbolic added value (Heller 2010; Heller \& Duchêne 2012; Heller, Pujolar \& Duchêne 2014), pragmatic value (Alsagoff 2008), ideological value (Gal 2012), exchange value (Heller 2010; Heller Pujolar \& Duchêne 2014), authenticity as value (Heller, Pujolar \& Duchêne 2014), and indexical value (Irvine 1989). Discussion of the value of commodities from classical or Marxist political economy is largely absent, as is discussion of work in applied linguistics that does employ specific notions of value, for example Grin's (2003) application of the utility theory of value, and Reksulak, Shughart \& Tollison (2004) on English valued as a network good. In lieu of in-depth considerations of theoretical approaches to value, there is often instead the tacit reproduction of a set of assumptions largely derived from neo-classical economics which correspond to favoured neoliberal conceptions in which value is conceived primarily in terms of want. The result has been a tendency to focus exclusively on consumption at the expense of considerations of production in discussions of the language commodity.

The common theme as regards discussion of the value of language, is the assumption that value is something bestowed on commodities discursively. For Alsagoff (2008), a language commodity is "given a value based on its association with some form of benefit or 'goods' of worth to the society" (p. 45). In a similar vein, for Heller (2010), speakers potentially "claim ownership of linguistic resources [...] and the value attributed to them" (p. 110), and for Lam \& Wang (2008), both the state and language users "periodically assign and re-assign value as appropriate" (p. 149). Here then we have value as something given, attributed, or assigned to the language commodity by people. For the sake of clarification, there is no doubt that discursive processes such as advertising, promotion, fashion etc. through indexing commodities in various ways bestow 'added value' upon commodities (Appadurai 1986). In this manner, commodities become 'cool', 'sexy', 'lifestyle choices', 'authentic', 'original' etc. and are discursively more desirable or 'valuable', in the broad sense of the term. However, all too often, this is where discussion reaches its limit, because the language commodity is discussed as valuable chiefly in the sense that it is desirable, and not as a product of expended human labour.

This assumption of value as outlined by Simmel (1978 [1900]), later drawn on by Appadurai (1986), forms the basis of the anthropological and applied linguistic discussion of value, particularly added value, in much of the work on the language commodity (Duchêne \& Heller 2012; Heller 2010; Heller \& Duchêne 2016; Heller, Pujolar \& Duchêne 2014). Simmel, a favourite among neoliberal economists according to Graeber (2001), rejected Marx's notion of value as embodied within commodities themselves, positing instead value as derived from subjective judgements made about objects. Here, objects are only valuable to the extent that they "resist our desire to possess them" 
(1978 [1900]: 67). In this sense of value, an object's value is determined by the extent to which its would-be-possessor is willing to sacrifice money, time, resources etc. in order to acquire it in exchange. Desire can of course extend well beyond value in the market, to become a pathological need or compulsion, as in the desire of parents for their children to learn English (Song 2011; Chowdhury \& Phan 2014) but this is not the sense which Simmel gives it. In summary, we might say that while Smith's and Marx's theories of value centre on production and labour, Simmel's focuses on exchange and demand in consumption. For Marx, the supposition that value comes from exchange alone is erroneous, as when supply and demand are in equilibrium they cease to explain anything about discrepancies in value between commodities of different kinds (Harvey 2010; Marx 1990 [1867]), rather, as we have argued, it is the socially necessary labour time required to produce the commodity that dictates value. This is not to say that supply and demand are in some sense illusory or insignificant, only that they are not solely responsible for determining the 'value' - in the broad sense - of a commodity. To suppose that supply and demand are the only, or even the primary, forces at work in determining a product's value, is therefore to neglect the importance of labour in the creation of value, and the reproduction of the social relations that define capitalism namely, the relation which exists between capital and labour.

The question of value returns us to the distinction we made earlier between commodities on the one hand, and things appearing as commodities on the other, where the former are embodiments of value produced by labour, and the latter have 'imaginary' value. It is one thing to claim that abstract entities such as honour or language may command an imaginary price (i.e. discursively-constructed value) in appearing as commodities. It is quite another, however, to imply that the price of all commodities is an imaginary relation, and that the value of commodities exists only in the mind - in short, that value and commodity status are attributed discursively. We readily acknowledge that scholars who frame language as a commodity make no such claim as regards commodities and value in general. However, it remains unclear whether such scholars regard the value of commodities as a whole to be a discursive matter. Such a proposition, we argue, is to succumb to the spell of fetishism, and to spirit away the role of labour in creating value in production. If commodities and value existed only in the mind, then it could be argued that the workings of capitalism itself are imaginary. But this is evidently not the case. At its core, an economy is a social organisation, it is therefore a thing which is made and remade through the activity of people (Bhaskar, 1998), even as the social mechanism of which the economy is a part precedes us, and is 'always already made' (ibid: 37). As Marx (1972 [1852]) also argues, "Men make their own history, but they do not make it as they please [...] [Rather, they make it] under circumstances directly found, given and transmitted from the past" (p. 595). To abstract away from the fact that it is people - or more precisely people's labour - which makes and remakes our material existence, even as it is always already made, runs the risk of mystifying capitalism as something natural, eternal and outside of the influence of people - it is to say capitalism is simply the way that it is. As Marx puts it, "If [...] we make the mistake of treating it [the capitalist mode] as the eternal natural form of social production, we necessarily overlook the specificity of the value-form, and consequently of the commodity" (Marx 1990 [1867]: 174, emphasis added). From a Marxist point of view, to treat value in purely discursive terms is to become preoccupied with a surface appearance, and to neglect what capitalism really is - namely, an historically specific and contingent humanmade form of production, that produces and reproduces itself through the duality of capital and labour. The language commodity is in this sense not really a commodity at all, and with no account of its production it sheds much of its critical momentum. 


\section{Conclusion: Towards A Marxist Approach to Language and the Commodity}

In this article we have shifted the focus of value from the object (the commodity) to the process (production of the commodity). It is the essential nature of capitalism that value lies in the processes of production of commodities, rather than in their physical character or in the human desire for them. As we have argued, the appearance of the language commodity - its use-value and its exchange-value duality in isolation - does not tell us a great deal about capitalism, while also assimilating language, no doubt unintentionally, to the individualist neoliberal vision of skills. In overlooking production and labour created value, scholars have tended to make little if any distinction between the language commodity and other commodities which are produced by labour, as both equally appear in the dual form of exchange-value and use-value. The result of this has been a discussion which is limited for the most part to an idealist understanding of consumption and exchange, where the material social relations involved in the realm of production remain obscured; and where languages such as English become 'commodities' with value merely because they are discursively constructed as such. The emphasis on commodification as a discursive phenomenon, and the occlusion of production and the role of labour therein, are in turn problematic for the claim that the analysis is able to throw light on the connections between the historical specificity of contemporary capitalism and the role that language plays within it. In this context, the foreshortening of the critique of neoliberal capitalism, is matched by an unfortunate ahistoricism in relation to 'valued' or 'instrumentalised' languages in world history. We contend that language commodification of the instrumentalist kind is not new, as the conferment of value on language almost certainly existed in antiquity under pre-capitalist modes of production, and remains extant in the present-day contexts of tribal communities living on the periphery of capitalist economic relations, or even outside them, such as in Irvine's example of the rural Wolof of Senegal (Irvine, 1989).

We have argued that in taking a Marxist political economy approach to the commodity, production should be brought back into the discussion of language and political economy, and avenues of enquiry opened up as to how the material social relations at the very heart of capitalism - capital and labour - interrelate with language. While we do not share the conviction that language is a commodity, we nevertheless recognise that a significant amount of production is dedicated to facilitating the teaching and learning of languages in terms of commodities like textbooks, dictionaries, DVDs, television programmes, computer programs, smartphone applications, and services such as language teaching and tutoring. With regard to the last of these, Block (2018) rightly points out that the teaching and learning of languages have largely been overlooked by scholars who take a political economy approach to language. A Marxist approach opens the door for scholars in applied linguistics and anthropology to investigate how "basic skills, knowledge of commerce and languages, etc., are reproduced ever more quickly, easily, generally and cheaply, the more the capitalist mode of production adapts teaching methods etc. to practical purposes" (Marx 1991 [1894]: 414-415). A Marxist political economy approach would offer insights into how the 'essence' of capitalist production - the capital-labour social relation, influences how these commodities and services are both produced (e.g. in language schools and centres) and consumed (e.g. by language learners). It is by bringing back into the discussion that which is historically specific and particular to capitalism - its mode of production - that we believe a better understanding of the interrelation between language and political economy is possible. By means of this interrelation, we have also presented this article as a contribution to the unravelling of a 'false dichotomy' between idealist and 
materialist approaches to the linguistic and anthropological study of our world, which Irvine (1989) and others called for nearly thirty years ago. In this vein, we align ourselves with what Jones (2004) has described as an historical materialist approach. According to Jones, this entails

bringing the discourse up against the social reality outside of it in order to disclose not just the potential and actual shaping effect of discourse on reality but also the contradictions between them, the ways in which the world constructed in discourse runs up against the real social life process and is diverted by or comes to grief on it, however 'dominant' that discourse may be. (Jones 2004: 116).

It is by juxtaposing the ideal - how languages are discursively attributed with value and appear as commodities - with the material, in for example the production of goods and services that facilitate the acquisition of those languages, that we may learn more precisely about the relation between language and capitalism, and about those who produce and reproduce these relations through their production and consumption. We see such an investigation bringing together ethnographic work on the production processes of commodities and services which facilitate language acquisition, and/or give a key role to linguistic work in labour processes, with work on the discursive indexing of languages as valuable through government policy, advertising, public discourse, the business community, and other discursive realms. Moreover, it should be framed through a deeper engagement with work that deals with political economy at the macro level (Block 2018). Such a synthesis would enable a more holistic view of the dialectical relation between supply and demand, production and consumption, and ultimately provide insights into the manner in which languages, their speakers, and the material world they inhabit are reproduced. A Marxist political economy approach which unites production with consumption would enable scholars interested in these matters to investigate more effectively, and with due theoretical rigour, the relationship between discursive constructions of language as being desirable or 'valuable', with the material realities of production which act not only to satisfy such desires, but also to stimulate demand in the market for production on an ever increasing scale (Harvey 2013), through advertising, marketing and influence in government policy making. As Marx shows us, the production and consumption of a range of commodities and services do not occur in isolation but influence each other as distinct instances or 'moments' of production that are inescapably interwoven, and which need to be 'grasped in their unity' (Marx 1973: 88). One might then be in a position to ask how the production of the myriad commodities and services that involve language - but are not in and of themselves language - are politically and economically functional in relation to the language which is a component of their existence, while also examining the relations between the various products and services on offer. These are issues which we argue should be high on the agenda for work that wishes to examine the relationship between the labour practices of contemporary capitalism and language, and we see a more rigorous engagement with political economy, specifically through a Marxist approach, as an apt theoretical frame for such an enquiry.

\section{References:}

Alsagoff, L. (2008). The commodification of Malay: Trading in futures. In P. Tan \& R. Rubdy (eds.), (pp.44-56).

Appadurai, A. (1986). Introduction: commodities and the politics of value, in A. Appadurai (ed.) The Social Life of Things (pp.3-63). Cambridge: Cambridge University Press. 
Becker, G. S. (1993). Human capital: A theoretical and empirical analysis, with special reference to education. $3^{\text {rd }}$ edn. Chicago: Chicago University Press.

Bhaskar, R. (1998). The Possibility of Naturalism: A Philosophical Critique of the Contemporary Human Sciences (3rd ed.). London: Routledge.

Block, D. (2014). Social class in applied linguistics. Routledge.

Block, D. (2018). What is language commodification? In S. Breidbach, L. Küster, \& B. Schmenk (eds.), Sloganizations in language education discourse. Bristol: Multilingual Matters.

Block, D., Gray, J., \& Holborow, M. (2012). Neoliberalism and applied linguistics. UK: Routledge.

Bourdieu, P. (1977). Outline of a Theory of Practice. Trans. by Richard Nice. Cambridge: Cambridge University Press.

Bourdieu, P. (1984). Distinction: A social critique of the judgement of taste. (R. Nice, Trans.). London: Routledge.

Bourdieu, P. (1986). The forms of capital. Handbook of Theory and Research for the Sociology of Education. Edited by: Richardson J. 1986. 241-258.

Bourdieu, P. (1991). Language and symbolic power. Cambridge: Polity Press.

Boutet, J. (2012). Language workers. Emblematic figures of late capitalism. In A. Duchêne \& M. Heller (eds.), (pp. 207-229).

Brumfit, C. (1991). Applied linguistics in higher education: Riding the storm. BAAL Newsletter 38, 4549.

Bruthiaux, P. (2008). Dimensions of globalization and applied linguistics. In P. Tan \& R. Rubdy (eds.), (pp.16-30).

Cameron, D. (2005). Communication and commodification. Language, Communication and the Economy. Amsterdam, The Netherlands/Philadelphia, Pennsylvania: John Benjamins.

Coulmas, F. (1992). Language and economy. Oxford: Blackwell.

Da Silva, E., McLaughlin, M., \& Richards, M. (2007). Bilingualism and the globalized new economy: The commodification of language and identity. In Bilingualism: A social approach (pp. 183-206). UK: Palgrave Macmillan. 
Del Percio, A., \& Duchêne, A. (2012). Commodification of Pride and Resistance to Profit. In A. Duchêne \& M. Heller (eds.), (pp. 43-73).

Flubacher, M., \& Del Percio, A. (eds.). (2017). Language, Education and Neoliberalism: Critical Studies in Sociolinguistics. Bristol: Multilingual Matters.

Duchêne, A. (2009) Marketing, management and performance: Multilingualism as a commodity in a tourism call center. Language Policy 8(1), 27-50.

Duchêne A, \& Heller M, (eds.) (2012). Language in Late Capitalism. Pride and Profit. New York: Routledge.

Fraser, N. (2014). Can society be commodities all the way down? Post-Polanyian reflections on capitalist crisis. Economy and Society, 43(4), 541-558.

Friedrich, P. (1989). Language, ideology, and political economy. American anthropologist, 91(2), 295312

Gal, S. (1989). Language and political economy. Annual Review of Anthropology, 18(1), 345-367.

Gal, S. (2012). Sociolinguistic Regimes and the Management of Diversity. In A. Duchêne \& M. Heller (eds.), (pp.22-42).

Gal, S. (2016). Language and political economy: An afterword. HAU: Journal of Ethnographic Theory, 6(3), 331-335.

Graeber, D. (2001). Toward an anthropological theory of value: The false coin of our own dreams. New York: Palgrave Macmillan.

Gray, J. (2010). The Construction of English: Culture, Consumerism and Promotion in the ELT Global Coursebook. UK: Palgrave Macmillan.

Gray, J. (2016). TESOL and the Discipline of English. In L. Prescott, A. Hewings, \& P. Seargeant (Eds.), Futures for English Studies: Teaching Language, Literature, and Creative Writing in Higher Education (pp. 81-98). London: Palgrave.

Grin, F. (2003). Language planning and economics. Current issues in language planning, 4(1), 1-66.

Grin, F. (2014). 50 years of economics in language policy. Critical assessment and priorities. ELF (English as a Lingua Franca) Working Papers 13, Université de Genève.

Grin, F., C. Sfreddo \& F. Vaillancourt (2010). The economics of the multilingual workplace. London/New York: Routledge. 
Harvey, D. (2005). A brief history of neoliberalism. Oxford: Oxford University Press.

Harvey, D. (2010). A companion to Marx's Capital (Vol. 1). London/NewYork: Verso Books.

Heller, M. (2002). 'Globalization and the commodification of bilingualism in Canada', in D. Block \& D. Cameron (eds.) Globalization and language teaching (pp. 47-63), London: Routledge.

Heller, M. (2003). Globalization, the new economy and the commodification of language. Journal of Sociolinguistics, 7 (4): 473-492.

Heller, M. (2010). The Commodification of Language. Annual Review of Anthropology. 39, pp.101-14.

Heller, M. (2010b). Language as Resource in the Globalized New Economy. In Coupland, N. (ed). The handbook of language and globalization (pp.349-65). Malden: Blackwell.

Heller, M., \& Duchêne, A. (2016). Treating language as an economic resource: Discourse, data and debate. In Coupland, N. (ed.) Sociolinguistics: Theoretical debates, (pp.139-156). Cambridge: Cambridge University Press.

Heller, M., Jaworski, A. \& Thurlow, C. (eds.) (2014). Linguistic commodification in tourism. Special issue of Journal of Sociolinguistics, 18(4).

Heller, M., Pujolar, J. \& Duchêne, A. (2014). Linguistic commodification in tourism. Journal of Sociolinguistics, 18(4), 539-566.

Holborow, M. (2015). Language and neoliberalism. London/New York: Routledge.

Hoon, C.H. (2008). Beyond linguistic instrumentalism: The place of Singlish in Singapore. In P. Tan \& R. Rubdy (eds.), (pp.57-69).

Irvine, J. T. (1989). When talk isn't cheap: Language and political economy. American ethnologist, 16(2), 248-267.

Jones, P. E. (2004). Discourse and the Materialist Conception of History: Critical Comments on Critical Discourse Analysis. Historical Materialism 12 (1): 97-125.

Kamwangamalu, N. M. (2008). Language policy, vernacular education and language economics. In P. Tan \& R. Rubdy (eds.), (pp.171-186).

Kelly-Holmes, H. (2016). Theorising the market in sociolinguistics. Sociolinguistics: Theoretical Debates, 157-172.

Kubota, R. (2016). The Multi/Plural Turn, Postcolonial Theory, and Neoliberal Multiculturalism: Complicities and Implications for Applied Linguistics. Applied Linguistics, 37(4), 474-494. 
Lam, A. S. L., \& Wang, W. (2008). Negotiating language value in multilingual China. In P. Tan \& R. Rubdy (eds.), (pp.146-170).

Lorenete, B.P. (2012). Commodification of Pride and Resistance to Profit. In A. Duchêne \& M. Heller (eds.), (pp. 183-206).

Marx, K. (1978 [1852]). 18th Brumaire of Louis Bonaparte. In R. C. Tucker (Ed.), The Marx-Engels Reader. New York: Norton.

Marx, K. (1973). Grundrisse. Harmondsworth: Pelican.

Marx, K. (1990 [1867]). Capital: Volume 1: A Critique of Political Economy (Penguin Classics).

Marx, K. (1991 [1894]). Capital: Volume 3: A Critique of Political Economy (Penguin Classics).

Marx, K., \& Engels, F. (1967 [1848]). The communist manifesto. Trans. AJP Taylor. London: Penguin.

McGill, K. (2013). Political Economy and Language: A Review of Some Recent Literature. Journal of Linguistic Anthropology, 23(2).

Muth, S. and Del Percio, A. (eds.) (forthcoming), Policing languages and speakers for commodification, Special Issue, Language Policy.

Muth, S., \& Ryazanova-Clarke, L. (Eds.) (2017). The commodification of Russian around the world. International Journal of Bilingual Education and Bilingualism, 20(4), 381-384.

Park, J. S. Y., \& Wee, L. (2012). Markets of English: Linguistic capital and language policy in a globalizing world. New York/London: Routledge.

Pujolar, J., \& Jones, K. (2012). Literary tourism: New appropriations of landscape and territory in Catalonia. In A. Duchêne \& M. Heller (eds), (pp. 93-115).

Rahman, T. (2009). Language ideology, identity and the commodification of language in the call centers of Pakistan. Language in Society, 38(2), 233-258.

Rampton, B. (1997). Retuning in applied linguistics. International journal of applied linguistics, 7(1), $3-25$.

Rassool, N. (2007). Global issues in language, education and development: Perspectives from postcolonial countries (Vol. 4). Clevedon: Multilingual matters. 
Reksulak, M., Shughart, W. F., \& Tollison, R. D. (2004). Economics and English: Language growth in economic perspective. Southern Economic Journal, 232-259.

Ricento, T. (2012). Political economy and English as a 'global' language. Critical Multilingualism Studies, 1(1), 31-56.

Rossi-Landi, F. (1977). Linguistics and economics. The Hague: Mouton.

Rossi-Landi, F. (1983). Language as work and trade: A semiotic homology for linguistics and economics. South Hadley, MA: Bergan \& Garvey.

Shankar, S. \& Cavanaugh, J. R. (2012). Language and materiality in global capitalism. Annual Review of Anthropology, 41, 355-369.

Simmel, G. ([1900]/1978). The philosophy of money, trans. T. Bottomore and D. Frisby. London: Routledge \& Kegan Paul.

Singh, M. \& Han, J. (2008). The commoditization of English and the Bologna process: Global products and services, exchange mechanisms and trans-national labour. In P. Tan \& R. Rubdy (eds.), (pp.204224).

Smith, A. (2003 [1776]). The wealth of nations, Bantam Classic Edition. New York: Bantam.

Song, J. J. (2011). English as an official language in South Korea: Global English or social malady? Language Problems \& Language Planning, 35(1), 35-55.

Tan, P. (2008). The English language as a commodity in Malaysia: The view through the medium of instruction debate. In P. Tan \& R. Rubdy (eds.), (pp.106-121).

Tan, P \& Rubdy, R. (Eds.). (2008). Language as commodity: Global structures, local marketplaces. Bloomsbury Publishing.

Tupas, T. R. F. (2008). Anatomies of linguistic commodification: The case of English in the Philippines vis-à-vis other languages in the multilingual marketplace. In P. Tan \& R. Rubdy (eds.), (pp.89-105).

Urciuoli, B. (2008). Skills and selves in the new workplace. American Ethnologist, 35(2), 211-228.

Wee, P. (2008). Linguistic instrumentalism in Singapore. In P. Tan \& R. Rubdy (eds.), (pp.31-43). 